\title{
Effects of Nd on Microstructures and Mechanical Properties of AM60 Magnesium Alloy in Vacuum Melting
}

\author{
Zhang Jinwang, Wang Shebin, Zhang Junyuan, Zhang Jinling, Xu Bingshe
}

Taiyuan University of Technology, Taiyuan 030024, China

\begin{abstract}
The microstructure changes brought by the addition of Nd element to AM60 magnesium alloy were studied, the precipitating phases were identified and their influences on the mechanical properties of alloys were investigated. Results show that $\mathrm{Nd}$ addition makes the refinement of microstructure of the $\mathrm{AM} 60$ alloy, and decreases the size of $\mathrm{Mg}_{17} \mathrm{Al}_{12}$ phase. Nd element takes a priority to react with $\mathrm{Al}$ element over $\mathrm{Mg}, \mathrm{Mn}$ and $\mathrm{Zn}$ forming binary phase $\mathrm{Al}_{11} \mathrm{Nd}_{3}$ with high melting point. Certain content of $\mathrm{Nd}$ can increase tensile strength, yield strength and elongation of the alloy. But with too much addition, $\mathrm{Nd}$ would combine with more $\mathrm{Al}$ in matrix and decrease strengthening effect because $\mathrm{Al}_{11} \mathrm{Nd}_{3}$ phase would become coarsening. The mechanical property tests indicate that AM60-0.9Nd alloy has the best properties. Maximum tensile strength, maximum yield strength, maximum elongation are 230 $\mathrm{MPa}, 127 \mathrm{MPa}$ and $14 \%$ respectively, increased by $28 \%, 48 \%$ and $250 \%$ respectively.
\end{abstract}

Key words: magnesium alloy; AM60 alloy; Nd; microstructure; mechanical properties

Magnesium alloys, as the lightest structural metal, are called green-engineering material in the 21 st century with great development potential in automobile, electronics and aerospace industries because of their high specific strength and stiffness, superior damping capacity, good electromagnetic shielding characteristics, excellent shock absorption and good machinability ${ }^{[1-3]}$. Since they can satisfy the need of weight saving, fuel economizing and reducing emission of $\mathrm{CO}_{2}$, magnesium alloys have been used to fabricate a variety of automobile parts, such as automobile wheel hubs, instrument panels, and steering wheels ${ }^{[4]}$. The applications of the most common magnesium alloys, such as AZ91 and AM60, account for $90 \%$ of total automobile magnesium alloys ${ }^{[5]}$. The ductility of AM60 alloy is better than that of AZ91, but the strength of AM60 is lower. In order to satisfy the properties of automobile wheel hubs, it is exigent to improve the mechanical properties of AM60 alloy.

At present, a variety of methods have been developed to refine magnesium-aluminum alloys, such as superheating, the Elfinal process, the addition of carbon or particles $\left(\mathrm{Al}_{4} \mathrm{C}_{3}, \mathrm{AlN}, \mathrm{SiC}, \mathrm{TiC}\right)$; of these methods, the addition of $\mathrm{FeCl}_{3}$ offers practical advantages because of the low oper- ating temperature involved. However, the problem of this method is the emission of harmful chloride gas; and the chloride and $\mathrm{Fe}$ remaining in the magnesium alloys will cause severe corrosion $^{[6,7]}$. Nd has many merits such as purifying alloy melt, modifying castability, refining the microstructure, improving the mechanical properties and anti-oxidization properties. In addition, our country is rich in magnesium resource and RE resource, so it is important to study high-property magnesium with $\mathrm{RE}^{[8-11]}$. However, study on the effects of $\mathrm{Nd}$ addition on mechanical properties of AM60 magnesium alloy is very limited. There is a very few of study on the smelting of AM60 alloy in vacuum.

In this study, to avoid the pollution caused by air and fusing agent in the process of smelting, the sample of magnesium alloy was smelted by adding $\mathrm{Nd}$ in Ar vacuum. The microstructures and mechanical properties tests were carried out by adopting 5 kinds of AM60 alloys with different $\mathrm{Nd}$ contents at room temperature and the effects of $\mathrm{Nd}$ were discussed. The results of this study will provide a reference to understand the effects of Nd on AM60 alloy and extend magnesium alloy application areas.

Received date: June 16, 2008

Foundation item: National Natural Science Foundation of China(90306014, 20471041)

Biography: Zhang Jinwang, Master, College of Materials Science and Engineering, Taiyuan University of Technology, Taiyuan 030024, P. R. China, Tel: 0086351-6010311, E-mail: xubs@public.ty.sx.cn

Copyright (C) 2009, Northwest Institute for Nonferrous Metal Research. Published by Elsevier BV. All rights reserved. 


\section{Experiment}

$\mathrm{Mg}, \mathrm{Al}$, and $\mathrm{Zn}$ were used as starting materials to prepare the AM60 alloy. Based on AM60 alloys, four Nd containing alloys were developed. Nd contents were in the range from $0.3 \%$ to $1.2 \%$ (mass fraction). The design composition of samples and the results of SPARKLAB and ICP testing are listed in Table 1.

The alloys were smelted and refined in ZRR-M10 vacuum resistance melting furnace, and the following is the details of the experiment. a) The sidewall of the furnace and non-corrosive steel crucible were cleaned, into which the starting materials were put, and the coated $\mathrm{Nd}$ powder was put into the alloy storehouse. b) The melting system was pumped to $10^{-3} \mathrm{~Pa}$, and Ar was filled into the furnace. c) When Ar was filled up to $10^{2} \mathrm{~Pa}$, the vacuum valve was shut. d) When the starting materials were heated up to $800 \pm 5{ }^{\circ} \mathrm{C}$, the $\mathrm{Nd}$ powder was added, and after the materials were stirred thoroughly, deposited for 18-20 min to refine magnesium alloy. e) At the temperature of $680 \pm 5{ }^{\circ} \mathrm{C}$, the alloy was cast. f) When the cast alloy was cooled, the furnace was opened, and the samples taken from the cast were used for analyzing and testing.

The compositions of samples were analyzed by SPARKLAB, and the content of Nd was measured by IRIS Intrepid II (ICP). The microstructure and morphologies of the secondary phases were characterized by field emission scanning electron microscope (FESEM, JSM-6700F) and optical microscope (NIKON 1500). Phase analysis was carried out by X-ray diffractometer (RAX-10), and the tensile properties test were conducted at room temperature by WDW-100KN stretcher.

\section{Results}

\subsection{Effects of Nd content on microstructure}

The optical microstructures of the as-cast AM60, AM60-0.6Nd, AM60-0.9Nd, AM60-1.2Nd alloy are shown in Fig.1a, b, c, d, respectively. XRD pattern of AM60 indicates that this alloy is mainly composed of $\alpha-\mathrm{Mg}$ and $\mathrm{Mg}_{17} \mathrm{Al}_{12}$ phase (Fig.2a). Some cramp discontinuous lumps are distributed in the boundary area and SEM observation indicates a divorced eutectic characteristic, as can be seen from Fig.3a. EDS analysis reveals AM60 is mainly composed of $\mathrm{Mg}$ and $\mathrm{Al}$ elements (Fig.3d), and $\mathrm{Mg}_{17} \mathrm{Al}_{12}$ is confirmed. SEM observation
Table 1 Chemical composition of experimental alloys

\begin{tabular}{ccccccc}
\hline \multirow{2}{*}{ Alloy } & \multicolumn{5}{c}{$\begin{array}{c}\text { Designation and actually composition/\% } \\
\text { (mass fraction) }\end{array}$} \\
\cline { 3 - 7 } & & $\mathrm{Al}$ & $\mathrm{Mn}$ & $\mathrm{Zn}$ & $\mathrm{Nd}$ & $\mathrm{Mg}$ \\
\hline No.1 & Before & 6 & 0.35 & 0.2 & --- & Bal. \\
& After & 6.04 & 0.381 & 0.207 & --- & Bal. \\
No.2 & Before & 6 & 0.35 & 0.2 & 0.3 & Bal. \\
& After & 5.81 & 0.343 & 0.201 & 0.289 & Bal. \\
No.3 & Before & 6 & 0.35 & 0.2 & 0.6 & Bal. \\
& After & 5.80 & 0.321 & 0.220 & 0.594 & Bal. \\
No.4 & Before & 6 & 0.35 & 0.2 & 0.9 & Bal. \\
& After & 5.83 & 0.329 & 0.217 & 0.899 & Bal. \\
No.5 & Before & 6 & 0.35 & 0.2 & 1.2 & Bal. \\
& After & 5.79 & 0.336 & 0.139 & 1.186 & Bal. \\
\hline
\end{tabular}

also shows some particles in the $\alpha-\mathrm{Mg}$, EDS results indicate that they are Al-Mn phase ${ }^{[12]}$ (Fig.3e), which frequently appear in AM60 alloy in normal form, like particle and square. Fig.1b, c, d show the optical microstructures of the as-cast AM60 alloys with different contents of $\mathrm{Nd}$. It can be seen that the grains of alloys can be refined and the volume and size of $\beta$ - $\mathrm{Mg}_{17} \mathrm{Al}_{12}$ are decreased in the as-cast microstructure by adding $\mathrm{Nd}$ element. A typical microstructure of AM60-0.9Nd is revealed in Fig.1c. The XRD indicates the as-cast microstructure of AM60-0.9Nd alloy is mainly composed of $\alpha$ phase, $\mathrm{Mg}_{17} \mathrm{Al}_{12}$ and $\mathrm{Al}_{11} \mathrm{Nd}_{3}$ phase (Fig.2b). Some polygon particles and a few needle-shaped particles emerge in the matrix as a result of the addition of about $0.9 \%$ (mass fraction) $\mathrm{Nd}$. Some polygon and rod-like particles are occasionally found in the microstructure, according to the results of XRD and EDS analysis its chemical formula is $\mathrm{Al}_{11} \mathrm{Nd}_{3}$ (Fig.3e). The further increase of $\mathrm{Nd}$ content leads to larger $\beta$ phase in the microstructure of AM60 alloy, shown in Fig.1d), and more needle-shaped particle appear in this alloy (Fig.3c).

\subsection{Effects of $\mathrm{Nd}$ content on tensile properties at room-temperature}

The as-cast yield strength, ultimate tensile strength and total elongation of the five alloys are shown in Fig.4. The tensile test results indicate that the $\mathrm{Nd}$ addition is beneficial to the improvement of elongation, as shown in Fig.4. The elongation attains the maximum value of $14 \%$ when the $\mathrm{Nd}$ content is up to $0.9 \%$ (mass fraction). Further increase of $\mathrm{Nd}$ content
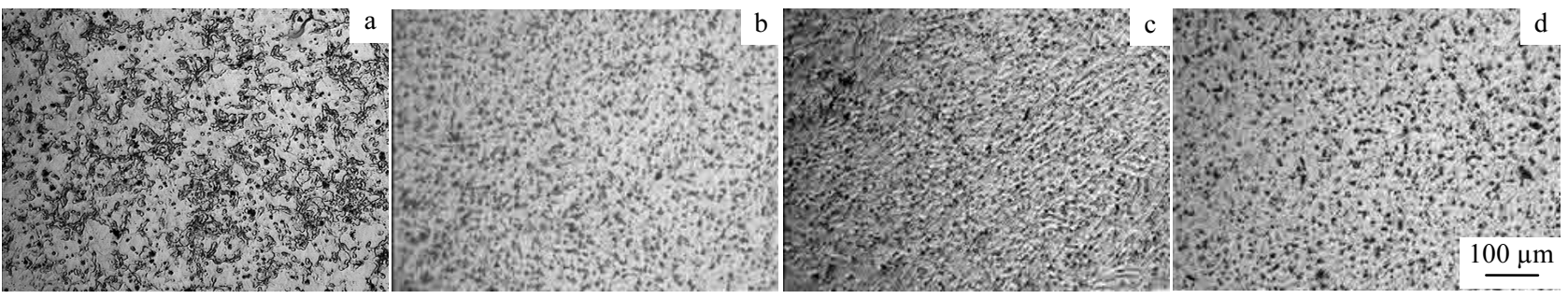

Fig.1 Optical microstructures of the cast alloy: (a) AM60; (b) AM60-0.6 Nd; (c) AM60-0.9 Nd; and (d) AM60-1.2 Nd 


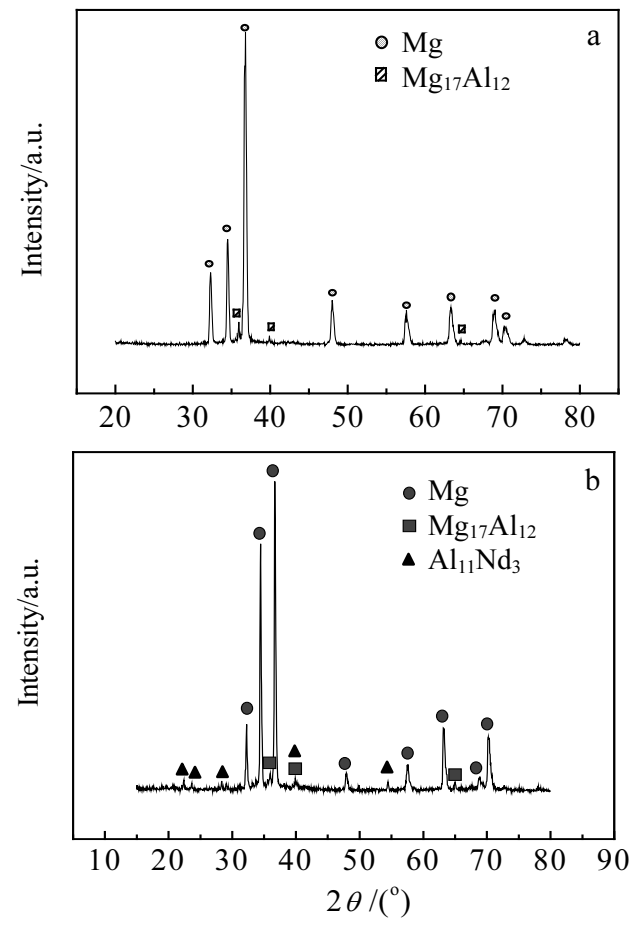

Fig.2 X-ray diffraction patterns: (a)AM60 and (b)AM60-0.9Nd

will lead to the decrease of elongation. The effect of Nd element on the ultimate tensile strength and the yield strength seems to be consistent with that on the elongation. The addition of about $0.9 \%$ (mass fraction) $\mathrm{Nd}$ leads to the maximum ultimate tensile strength and yield strength value, which 230
$\mathrm{MPa}$ and $127 \mathrm{MPa}$ respectively. Compared with AM60 alloy, AM60-0.9Nd alloy shows an increment magnitude with about $50 \mathrm{MPa}$ for the ultimate tensile strength, and about $40 \mathrm{MPa}$ for the yield strength. Further increase of $\mathrm{Nd}$ content leads to dropping trend of the ultimate tensile strength and the yield strength, but the decrease of the yield strength is not so obvious.

\subsection{Effects of $\mathrm{Nd}$ content on tensile fracture}

Magnesium alloy has a hcp structure, whose failure usually takes on brittleness through cleavage or quasi-cleavage fracture $^{[13]}$. Fig.5a, b, c, d show SEM images of tensile fractographs at room temperature for AM60, AM60-0.6Nd, AM60-0.9Nd, AM60-1.2Nd, respectively. Fig.5a is the image of AM60 alloy, which shows the well-developed river pattern and distinct cleavage steps. Fig.5b, c, d indicate that the addition of $\mathrm{Nd}$ in the AM60 alloy causes plenty of tearing ridges, tiny dimples and cleavage steps on the tensile fractures of the samples. The addition of $\mathrm{Nd}$ changes the $\beta-\mathrm{Mg}_{17} \mathrm{Al}_{12}$ (cubic structure) into thin, dense and non-continuous phase, and plenty of tearing ridges and tiny dimples appeared on the tensile fractures resulting in increasing of the ductility and toughness. So, the AM60 alloy has better ductility and toughness by adding $\mathrm{Nd}$ element.

\section{Discussion}

When Nd element is added into AM60 alloy, great effects of $\mathrm{Nd}$ element on the solidification behavior of the alloy can be found, as $\mathrm{Nd}$ element is possessed of characteristics of big atom size and slow diffusion rate. In the process of solidifica-
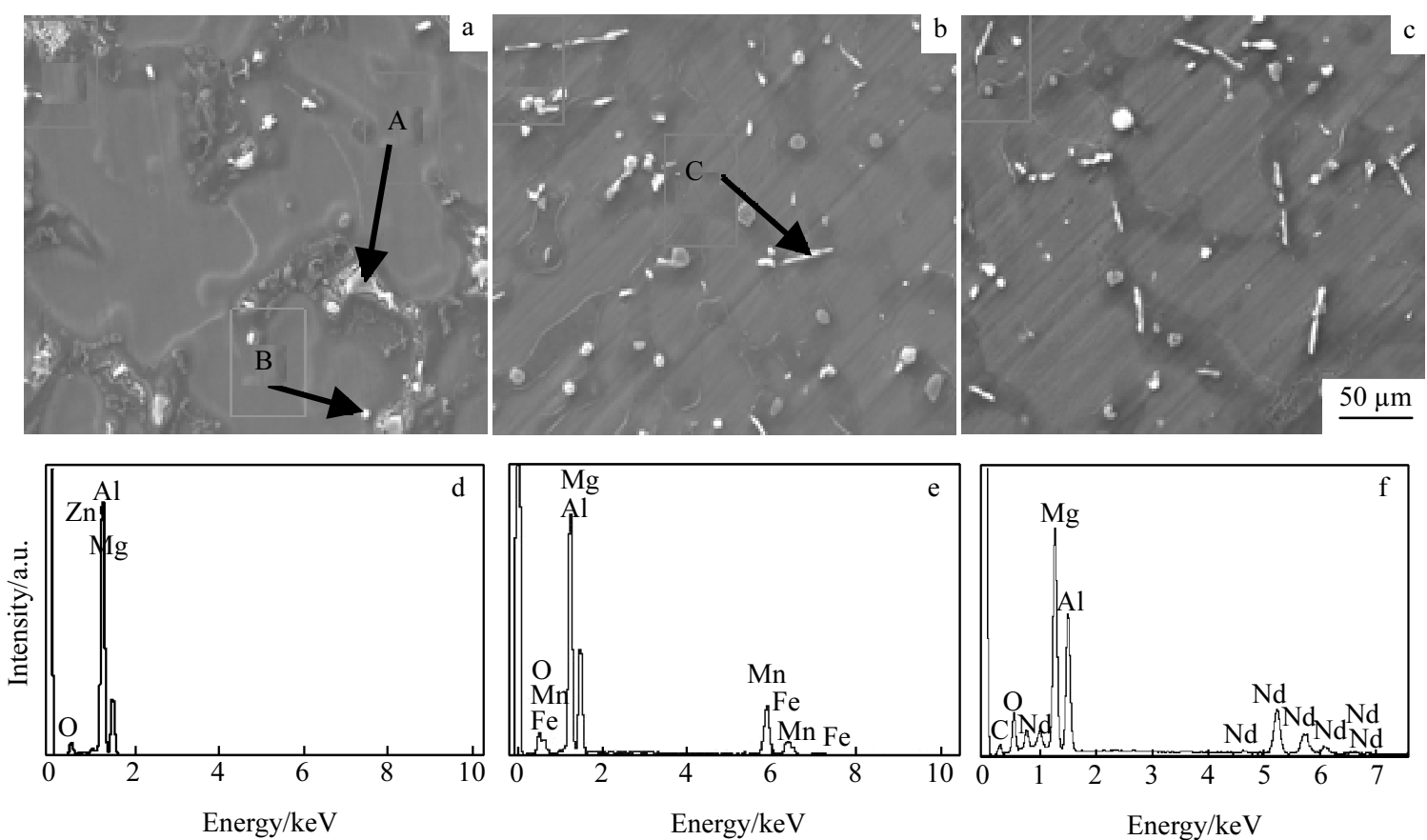

Fig.3 SEM images AM60 alloy: (a) AM60 alloy; (b) AM60-0.9 Nd; (c) AM60-1.2 Nd; (d) EDS of point A; (e) EDS of point B; and (f) EDS of point $\mathrm{C}$ 


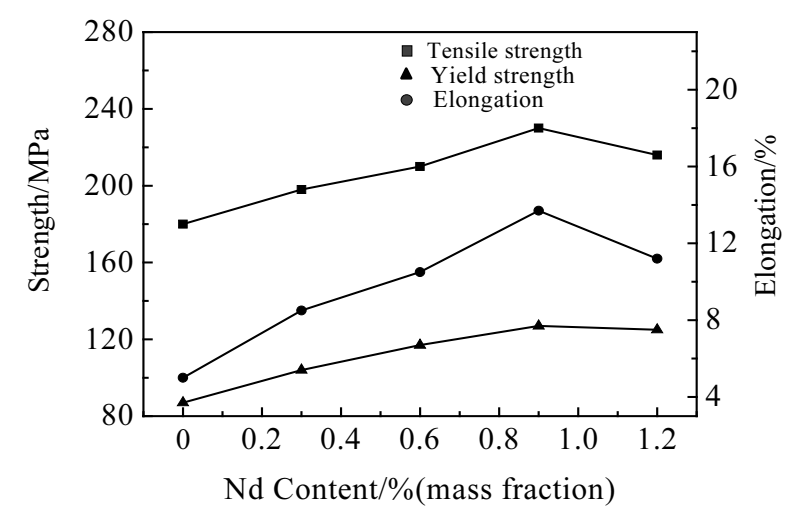

Fig.4 The relationship between the room-temperature tensile properties and $\mathrm{Nd}$ content in as-cast alloy

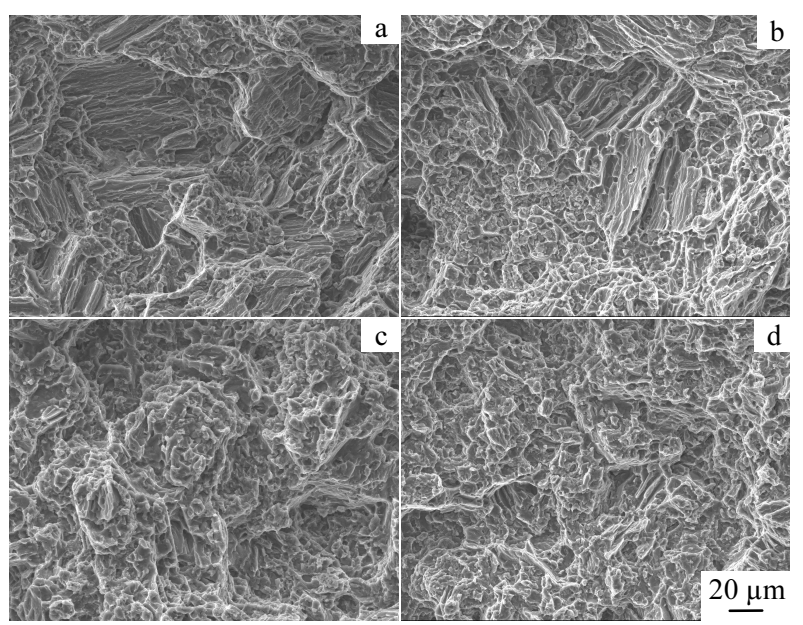

Fig.5 Tensile fracture micrographs of AM60 alloys: (a)AM60; (b)AM60-0.6 Nd; (c) AM60-0.9 Nd; and (d) AM60-1.2 Nd

tion, the solution elements such as $\mathrm{Nd}$ and $\mathrm{Al}$ will be separated from the primary $\alpha-\mathrm{Mg}$, and be concentrated at the solid/ liquid interface; thus constitutional under-cooling will appear in the diffusion layer ahead of the advancing solid/ liquid interface, and grain growth is restricted because the diffusion of the solute occurs slowly. Therefore, the as-cast microstructure can be refined by adding of RE elements. The compound phase with $\mathrm{Nd}$ element can be formed from the residual melt, in which $\mathrm{Nd}$ and $\mathrm{Al}$ elements are enriched after the solidification of the primary $\alpha-\mathrm{Mg}$. The $\mathrm{Al}_{11} \mathrm{Nd}_{3}$ phase will be formed prior to appearing of the $\beta-\mathrm{Mg}_{17} \mathrm{Al}_{12}$ phase on the grain boundary, because its formation temperature is about $150{ }^{\circ} \mathrm{C}$ higher than that of $\beta-\mathrm{Mg}_{17} \mathrm{Al}_{12}$ phase. The size of $\beta-\mathrm{Mg}_{17} \mathrm{Al}_{12}$ can be decreased by the precipitation of $\mathrm{Al}_{11} \mathrm{Nd}_{3}$ phase.

In the present work, the addition of $\mathrm{Nd}$ can greatly improve tensile properties of AM60 alloys at ambient temperature. The main strengthening mechanisms include: solid solltion strengthening, fine-grained strengthening and second phase strengthening. The morphologies of the alloys also have effect on the tensile properties ${ }^{[14]}$. (1) Concerning refinement strengthening, grain size has great effect on mechanical properties. Addition of $\mathrm{Nd}$ has great effect on the refinement of microstructure, because the size of $\beta-M_{17} \mathrm{Al}_{12}$ phase decreases. So the tensile properties of AM60 alloy are much improved. (2) Concerning solid solution strengthening, solid solubility of $\mathrm{Nd}$ in magnesium alloy is higher. After $\mathrm{Nd}$ is solved in Mg matrix phase, the solute atoms lead to nonspherical symmetrical distortion, so $\mathrm{Nd}$ also has great effect on the mechanical properties of magnesium alloy than any other RE elements. (3) Concerning second-phase strengthening, the granular particles are in favor of the tensile properties, while the needle-shaped particles do harm to the tensile properties because of the easy crack formation caused by the stress concentration between the interface of the particle and the matrix. When Nd element is added into AM60 alloy, the size of $\beta-\mathrm{Mg}_{17} \mathrm{Al}_{12}$ can be decreased, and the $\beta-\mathrm{Mg}_{17} \mathrm{Al}_{12}$ particles will be turned into fine spherical particles and their distribution became uniform. The discontinuous precipitation of $\mathrm{Mg}_{17} \mathrm{Al}_{12}$ phases is effectively suppressed because it ha del eterious effect on mechanical properties of $\mathrm{Mg}-\mathrm{Al}$ alloys ${ }^{[15]}$. So the addition of trace $\mathrm{Nd}$ can improve the mechanical properties. In addition, precipitation of $\mathrm{Al}_{11} \mathrm{Nd}_{3}$ phase has a beneficial effect on mechanical properties of magnesium alloy, but the $\mathrm{Al}_{11} \mathrm{Nd}_{3}$ phase with a tapering morphology in $1.2 \%$ RE-containing AM60 alloy is detrimental to the tensile properties in despite of the relatively uniform distribution. The conclusion can be drawn that the combination effect of the above mentioned strengthening mechanisms will bring AM60 alloy the great improvement of mechanical properties.

\section{Conclusion}

1) The as-cast microstructure of AM60 alloy is mainly composed of $\alpha-\mathrm{Mg}$ and $\mathrm{Mg}_{17} \mathrm{Al}_{12}$ phase. Addition of $\mathrm{Nd}$ is much beneficial to refining the microstructure of AM60 alloy, and at the same time causes a morphological change in $\mathrm{Mg}_{17} \mathrm{Al}_{12}$ particles from discontinuous precipitation to small polygonal type, resulting in the decrease of size of $\beta-\mathrm{Mg}_{17} \mathrm{Al}_{12}$.

2) AM60 has the best properties when the addition of $\mathrm{Nd}$ is $0.9^{\circ}$ (mass fraction), but further increase of $\mathrm{Nd}$ content will lead to the decreased of properties.

\section{References}

1 Mordike B L, Ebert T. Materials Science and Engineering[J], 2001, A302(1): 37

2 Friedrich H, Schumann S. Journal of Materials Processing Technology[J], 2001, 117: 276

3 Zeng Rongchang(曾荣昌), Ke Wei(柯 伟), Xu Yongbo(徐永波), et al. Acta Metallurgica Sinica(金属学报)[J], 2001, 37(7): 673

4 Tian Zheng(田 政), Song Bo(宋波), Liu Yongbing(刘勇兵). Automobile Technology and Material(汽车工艺与材料) [J], 2004, 7: 21 
5 Peng Yinghong, Li Dayong, Wang Yingchun. Materials Science Forum[J], 2005, 488 489: 393

6 Lee Y C, Dahle A K, Sbjohn D H. Metallurgical and Materials Transaction[J], 2000, 31A: 2895

7 Yosuke Tamura, Tadashi Haitani, Eiji Yano. Materials Transactions[J], 2002, 43(11): 2784

8 Rosalbino F, Angelini E, De Negri S et al. Intermetallics[J], 2005, 13: 55

9 Wang Mingxing, Zhou Hong, Wang Lin. Journal of Rare Earths[J], 2007, 25: 233

10 Liu Ying, Chen Weiping, Zhang Weiwen. Journal of Rare Earths[J], 2004, 22(4): 527

11 Liu Shengfa(刘生发), Wang Huiyuan(王慧源), Kang Liugen(康 柳根) et al. The Chinese Journal of Nonferrous Metals(中国有色
金属学报)[]], 2006, 13(6): 464

12 《Handbook of Light Metal Processing》 Compile Group(《轻合 金材料加工手册》编写组). Handbook of Light Metal Processing(轻合金材料加工手册)[M].Beijing: Metallurgical Industry Press, 1980: 367

13 Lü Yizhen(吕宜振). The Microstructures and Properties of $M g-A l-Z n$ Alloy(Mg-Al-Zn 合金的显微组织和性能)[D]. Shanghai: Shanghai Jiaotong University, 2001

14 Huang Xiaofeng(黄晓锋), Wang Qudong(王渠东), Zeng Xiaoqin(曾小勤) et al. Journal of the Chinese Rare Earth Society(中 国稀土学报)[J], 2004, 22(4): 493

15 Zhao Peng, Wang Qudong, Zhai Chunquan et al. Materials Science and Engineering [J], 2007, A444: 318

\title{
真空条件下Nd对AM60镁合金组织与性能的影响
}

\author{
张金旺, 王社斌, 张俊远, 张金玲, 许并社
}

(太原理工大学, 山西 太原 030024)

\begin{abstract}
摘 要: 研究了稀土 $\mathrm{Nd}$ 对 AM60 镁合金组眫影响 ，并分析析出相及其对合金力学性能的影响。结果表明, 在 AM60 合金中加入稀土 $\mathrm{Nd}$ 元素能有效地细化合金组织, 使 $\mathrm{Mg}_{17} \mathrm{Al}_{12}$ 相分离变细; $\mathrm{Nd}$ 元素优先与合金中的 $\mathrm{Al}$ 元素反应生成二元高熔点 $\mathrm{Al}_{11} \mathrm{Nd}_{3}$ 相; 适量的稀土 $\mathrm{Nd}$ 能有效提高合金的抗拉强度、屈服强度和延伸率; 过量的稀土 $\mathrm{Nd}$ 则会消耗合金中更多的 $\mathrm{Al}$ 元素和导致 $\mathrm{Al}_{11} \mathrm{Nd}_{3}$ 相粗化，使合金的 力学性能下降; 力学性能测试结果表明, AM60-0.9Nd 具有最高的抗拉强度 $(230 \mathrm{MPa}$ )、最高的屈服强度(127 MPa)和最高延伸率 (14\%), 分别比基体合金提高 $28 \%$ 、48\%和 $250 \%$ 。
\end{abstract}

关键词：镁合金; AM60 合金; $\mathrm{Nd}$; 微观组织; 力学性能

作者简介: 张金旺, 男, 1962 年生, 硕士, 太原理工大学材料科学与工程学院, 山西 太原 030024, 电话: 0351-6010331, E-mail: xubs@public.ty.sx.cn 